\title{
Ichthyological Contributions.
}

\author{
By
}

J. T. Cunningham, M.A.

With Plate XIV.

\section{Zeugopterus norvegicus (GÜnther).}

In my paper in the preceding number of this Journal I erroneously described several specimens of this species as Zeugopterus punctatus, not having carefully examined or compared them. Since then, having seen specimens of Zeugopterus norvegicus, and re-examined my own, I find that my specimens belong to this species. The record of their capture in the neighbourhood of Plymouth is-

July 9th, 1891, between Eddystone and Rame Head, 25 fms., four specimens, 3 o , $6.2,6.5,9.5 \mathrm{~cm}$. ; 1 \% $8.2 \mathrm{~cm}$. in length.

March 21st, 1892, six miles from Plymouth Breakwater, about 27 fathoms, one specimen,$+ 8.4 \mathrm{~cm}$. long. The last specimen was a ripe female, yielding ripe ova $.9 \mathrm{~mm}$. in diameter, with a single oil-globule $\cdot 15 \mathrm{~mm}$. in diameter.

In Günther's British Museum Catalogue, 1862, this species was only stated to occur on the west coast of Norway. In 1864 Couch recorded the capture of a specimen in the Bristol Channel in 1863. In a paper published in 1888 Günther recorded that he had obtained a specimen 2 inches long in 1868 from a depth of 90 fathoms off Shetland, and that three specimens taken in the Firth of Clyde, at depths of 6 to 45 fathoms, occurred among fishes captured by Mr. John Murray on the west coast of Scotland in 1887 and 1888. Two of the Clyde specimens were $3 \frac{1}{2}$ inches $(8.9 \mathrm{~cm}$.) long, the third somewhat smaller. Lastly, Mr. Holt obtained a specimen during the survey of the fishing-grounds on the west coast of Ireland in the s.s. Harlequin in 1891. This specimen was obtained at 30 fathoms in Donegal Bay in May, 1891, and is recorded in Mr. Holt's report on the survey, published in the Report of the 
Council of the Royal Dublin Society for 1891, and also in the Proceedings of that Society, vol. vii, pt. 4.

It was the inspection of this Irish specimen which led me to identify my own, and I have to thank Mr. Holt for kindly supplying me with references to the literature of the subject. I have now given all the recorded occurrences of this species on British coasts, and it will be seen that it appears to be occasionally fairly common in the Firth of Clyde and off Plymouth Sound, while only single specimens have been taken in the Bristol Channel, Donegal Bay, and off the Shetland Isles.

The species was originally described by Scandinavian zoologists, but first correctly distinguished by Günther. Couch's description and figure are fairly good, but not so satisfactory as those given by Günther in his report on Mr. Murray's collection from the west of Scotland. Day unfortunately failed to recognise the validity of Couch's description of this species, and placed the name used by that author as a synonym of Zeugopterus unimaculatus; and as I generally use Day's work, this was the reason that I at first confused the species with $Z$. punctatus. I prefer to use the generic name Zeugopterus for this form, rather than Rhombus, with which Günther unites it, on account of its evident affinities with Z. punctatus, and the difference between these forms and the turbot or brill. One important character, which unites the so-called topknots, namely, unimaculatus, punctatus, and the present species, is that the dorsal and post-anal fins are prolonged posteriorly on to the lower side at the base of the tail, towards the middle line of that side. The following is a list of the passages relating to Zeugopterus norvegicus cited in the preceding remarks :

J. Couch, Fishes of British Islands, 1864, vol. iii, p. 175, pl. clxvii.

Albert Günther, Brit. Mus. Catalogue, vol. iv, p. 412.

Idem, Report on Fishes obtained by Mr. J. Murray, \&c., Proc. Roy. Soc. Edinburgh, No. 127, Session 1887-8, p. 217, pl. iv.

E. W. L. Holt, Report on the Results of Fishing Operations, Survey of Fishing-grounds of West Coast of Ireland, Proc. Roy. Dubl. Soc., vol. vii, pt. 4.

Idem, Preliminary Note on the Fish obtained during the Cruise of the s.s. "Harlequin," 1891, Proc. Roy. Dubl. Soc., vol. vii, pt. 3, p. 218.

Zeugopterus punctatus is by no means uncommon in the neighbourhood of Plymouth. It is frequently taken by shrimp trawlers in the Sound, and brought in alive to our aquarium. I have four specimens, $11 \cdot 4$ to $15 \mathrm{~cm}$. ( $4 \frac{1}{2}$ to $5 \frac{7}{8}$ inches) in length; and also a young specimen $5 \mathrm{~cm}$. long, taken in the Sound on October 2 lst, 1889. 
This specimen was probably only six or seven months old, having been hatched in the preceding spring.

Zeugopterus unimaculatus, Risso, must be extremely rare on this coast. I have never yet met with a specimen. The collection made by Mr. Murray in 1887 and 1889 included only one specimen, taken in the Firth of Clyde off Ardrossan.

\section{On a Stage in the Metamorphosis of Solea.*}

\section{Plate XIV, fig. 2 .}

The larva represented in fig. 2 was obtained by Mr. F. W. Gamble on August 9th, when working with a hand-net among the fronds of Laminaria on the inner side of Plymouth Breakwater. It evidently belongs to the genus Solea from the shape of the snout, mouth, and head generally. The larva was $11 \mathrm{~mm}$. long. The dorsal fin-rays are eighty-six in number, the post-anal sixty-eight, so that it is certainly either Solea vulgaris or lascaris. I have not been able to discover any indication of the enlarged nostril on the lower side which distinguishes lascaris, and am therefore inclined to believe that the specimen belongs to the common sole. The chief difficulty in thus regarding it is the date of its occurrence. I have taken completely metamorphosed young soles in Mevagissey Harbour on May 15th, but they have not been seen there later. However, I know that a few soles are spawning in May, although a great many are then spent. But the larva here in question could not be much more than a month or five weeks old, and must, therefore, have been spawned late in June or early in July. It is possible that some soles spawn as late as this, although I have not observed any ripe specimens in these months. The specimen when alive was very transparent, as shown in the figure. The drawing was made with the camera lucida, so that its proportions are accurately correct to scale; but the exact number of the fin-rays has not been reproduced in the figure.

There are several points of interest and importance in this larva. It shows in the first place that in Solea, as in the genus Pleuronectes - the plaice and flounder, for example-the eye of the lower side passes round the edge of the head to reach the upper side, and not

* While these pages were in the press I noticed, on referring to Raffaele's paper (Mitt. Zool. Stat. Neapel, Bd. viii, tav. iii, figs. 8,9), that a similar stage of Solea is there described and figured. Thus the fact that the left eye reaches the right side in Solea by passing in front of the dorsal fin was already known, but as Raffaele's description and figures scarcely do full justice to this intermediate stage, the description and figure I have given are by no means superfluous. 
through the tissues of the base of the anterior part of the dorsal fin. It is well known that Steenstrup in 1863 described transition stages of Pleuronectids, obtained from the North Atlantic, in which the eyes, after metamorphosis, were on the left side, and the right eye passed through the head to reach that side. He considered these stages to belong to the genus Plagusia. Agassiz in 1878 (Proc. Amer. Acad. Arts and Sci., vol. xiv) described transition stages, quite similar to those of Steenstrup, captured at the mouth of Newport Harbour, and ascribed them likewise to the genus Plagusia. Emery, the Italian ichthyologist, has pointed out that these specimens of Steenstrup and Agassiz certainly do not belong to the genus Plagusia, because in the latter the dorsal and postanal fins are continuous with the caudal, and in these specimens they are quite distinct and separate. Without discussing the question at length, or carefully examining the evidence, Emery suggests that the North Atlantic specimens belong to the genus Rhomboidichthys. Emery, in the same paper, describes another larval form in which the longitudinal fins are continuous with the caudal, and the right eye passes through the base of the dorsal fin to the left side of the head. He did not succeed in identifying this larva with any known adult species. The larvæ in which this process of perforation has been hitherto described are sinistral, the eyes are on the left side; but nevertheless, considering the great anterior prolongation of the dorsal fin in the adult sole, it seemed not impossible that the migration of the lower eye should take place in that species also by perforation. The larva now described proves that this is not the case, its dorsal fin being still behind the left eye. The left eye has not quite reached the edge of the head; it is still on the left side, but it is very near the edge ; and when the larva is examined on a slide, lying flat on its left side, the cornea of the left eye is seen to project slightly beyond the edge of the head, as seen in the figure.

The next important feature in this larva is the presence of an air-bladder of considerable size. Hitherto, so far as I am aware, an air-bladder in larval Pleuronectidæ has only been observed in the turbot and brill. I have never seen a trace of it in species of Pleuronectes. In that stage of the flounder which corresponds to the stage of Solea here described, and which I have frequently examined, no trace of an air-bladder is visible (compare the pl. xvii, fig. 5, of my Treatise on the Sole). No air-bladder is present in the adult sole; and in the stage just after the completion of the metamorphosis, when the little sole is 12 to $15 \mathrm{~mm}$. long, the organ has already disappeared (see pl. xvi, fig. 5, op. cit.).

It is interesting to notice that in this larval stage some of the specific characters are already developed. I refer especially to the 
shape of the snout and the position and structure of the mouth. The edge of the upper lip on the right side is curved, as in the adult sole; teeth are absent from the jaws on the right side, present in the lower jaw on the left. The intestine, however, does not reach its adult condition till a much later period. In this stage it has only one coil, and the posterior part does not extend backwards behind the median body-cavity. The coloration is not reproduced in the figure: it consisted of black and orange specks (chromatophores) and more diffuse patches of lemon-yellow. The pigment was not arranged in the markings which characterise the adult, and which are already visible in the early post-larval stage figured in my treatise. On the body and head the specks were pretty uniformly distributed, but on the dorsal fin there were three pigmented regions, one at the anterior end, one in the middle, and one near the posterior end. On the post-anal fin there was only one pigmented area of considerable extent, opposite the posterior area of the dorsal fin.

In my Treatise on the Sole I was only able to figure the newly hatched larvæ and the earliest post-larval stage. Three other larval stages were figured and described in vol. ii, No. 1 of this Journal (pl. iii). The stage here described is intermediate between the latter and the first post-larval stage, and fills up an important gap in the series, although additional intermediate stages are still required. My use of the terms larval and post-larval differs from that adopted by Professor McIntosh and some of his pupils, who restrict the former term to the stages prior to the absorption of the yolk, and call subsequent stages post-larval. I cannot see any justification for this application of the terms. A fish is a larva until the most important organ-systems of the adult, such as the permanent skeleton and fins, are developed.

\section{A Larval Stage of the Mackerel.}

Plate XIY, fig. 1.

IN the first number of the current volume of this Journal (vol. ii, No. 1, p. 71, pl. iv, fig. 7) I described and figured the newly hatched mackerel larva. Last year I made further experiments in hatching and rearing the larvæ of this species from artificially fertilized eggs, using a hatching box of Captain Dannevig's pattern. I succeeded in keeping some of the larvæ alive four days after hatching, and the condition then reached is shown in fig. 1.

In this stage the yolk is almost entirely absorbed, but a remnant 
remains containing the oil-globule, which is still conspicuous. The mouth is developed and open, and indications of the gill arches are seen behind the head. The intestine has increased so much in length that it makes a single coil in the neighbourhood of the stomach. The pectoral fin is rather large. The choroid of the eye is deeply pigmented. With regard to the pigmentation of the skin, only the position of the chromatophores is represented in the figure. The black were arranged in a series along the dorsal and ventral edges of the body, and in a group about the oil-globule. There was no pigment at all in the larval median fin-fold. The iris of the eye appeared bright blue, and there was a large irregular patch of light yellow close behind the eye on the side of the head. In my figure of the newly hatched larva I represented the pigment as black and green, the green colour being present not only behind the eye, but round the oil-globule and at three other points. The explanation of the difference is that the green colour is due to the mixture of black and yellow pigments, as in the adult mackerel. In the larva at present described the yellow pigment is not mixed with the black, and its appearance is therefore not altered. I do not suppose that the distribution of pigment in the larva now described is absolutely constant in all larvæ at this stage-on the contrary, I believe it is subject to considerable individual variation; but the absence of chromatophores from the median fin-fold appears to be constant and characteristic of the mackerel.

\section{DESCRIPTION OF PLATE XIV.}

Fig. 1.-Larva of Scomber scomber, the mackerel, drawn June 15th, 1891, hatched June 11th. Zeiss $A_{3}$, oc. 3, camera. Actual length $4: 3 \mathrm{~mm}$.

FIG. 2.-Larva of Solea vulgaris (or S. lascaris), caught August 9th, 1892. Drawn from life with camera lucida. Actual length $11 \mathrm{~mm}$. $a, b$. Air-bladder.

\section{Growth of Young Herring in the Thames Estuary.}

I AM indebted to Mr. E. W. H. Holdsworth, author of the wellknown work on Deep Sea Fishing and Fishing Boats, for some references to passages bearing on this subject which had not come under my notice when I wrote my paper on the Rate of Growth of Sea Fishes for the previous number of this Journal. In that paper (see last number, pp. 240, 241) I stated that I had been unable to find any record of observations on the spawning of herring at the mouth of the Thames in spring. Mr. Holdsworth has directed my 


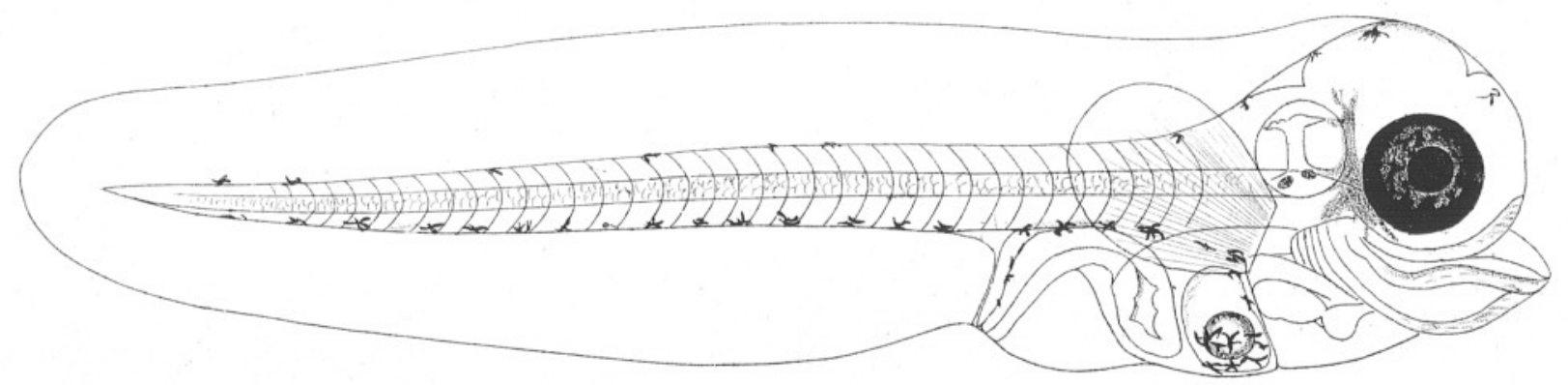

\section{Fig. 2}

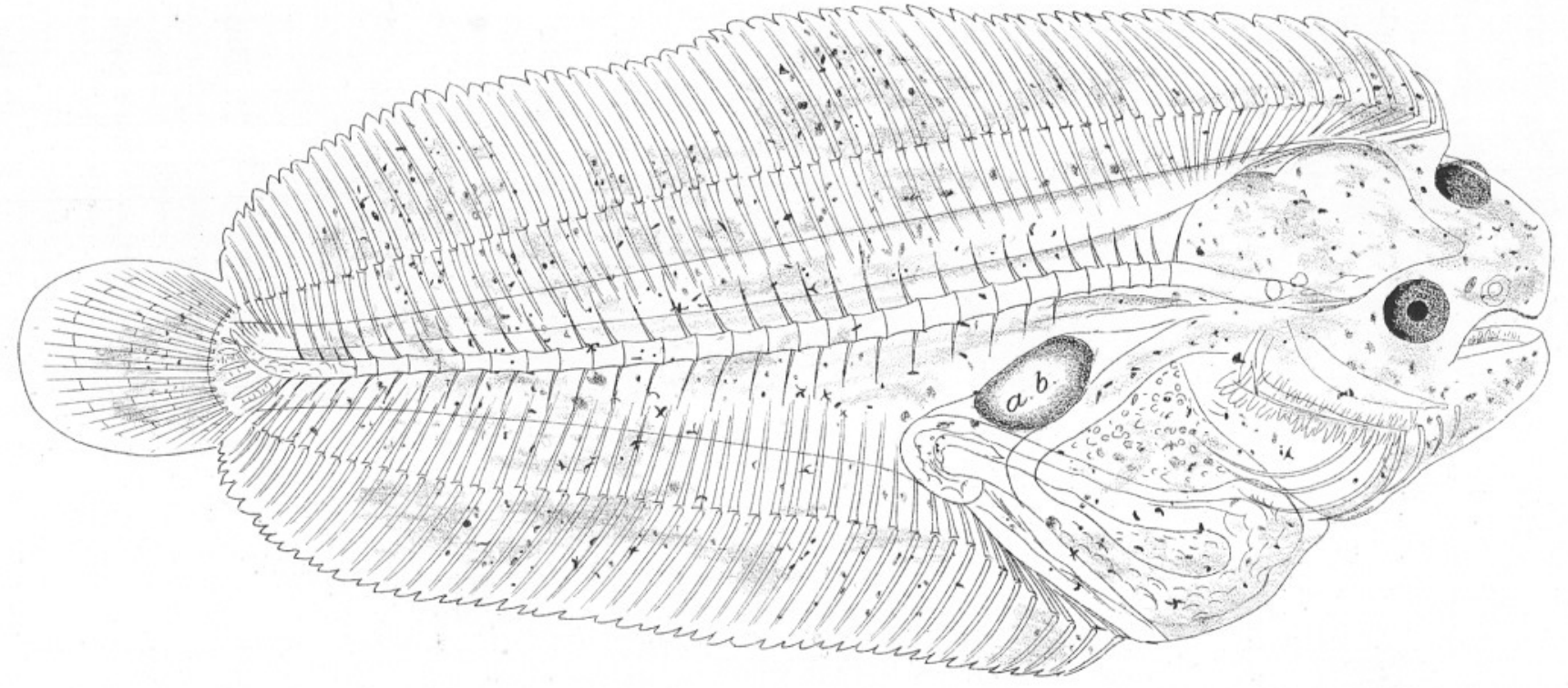


attention to such a record in Yarrell's British Fishes. In that work, first edition, 1836, vol. ii, p. 117, is an account of what the author believes to be a distinct species of herring, which he calls Leach's herring, Clupea Leachii. Yarrell says that he found herring of this sort among the fish taken at the mouth of the Thames during winter by the sprat fishermen. He points out that the common herring deposits its spawn towards the end of October, and says that numbers of the young of these herring are taken with the sprats. These are yearling herring, have the elongated form of the common herring, and although reaching 7 inches in length are without roe. The herring of the new species is found heavy with roe at the end of January, and does not deposit its spawn till the middle of February. Its length is not more than $7 \frac{1}{2}$ inches, and its depth near 2 inches. The characters by which Yarrell distinguishes this species from the common or autumn herring are not very salient, but it is quite possible that they correspond to those in which, according to Heincke, the spring race of herrings differs from the autumn race. The principal are the greater depth of the body and the more anterior position of the dorsal fin. However, whether these herrings are structurally distinct or not, the important fact is that Yarrell found them spawning in the middle of February. I inferred in my previous paper, from the occurrence of the larval herrings in Thames whitebait, that the parents of the latter spawned in March, April, and May; and it is not improbable, considering that Yarrell did not fully determine the limits of their spawning period, but only states that they did not spawn until the middle of February, that he only noticed the commencement of the spawning, which may have continued till the middle of May. $\mathrm{Mr}$. Holdsworth, in his book on Deep Sea Fishing, p. 249, refers to Yarrell's account of Leach's herring in the Thames, stating that a more extensive examination has resulted in ranking it only as one of the numerous races of the common herring. He states also that this "small variety" of herring appears in the Wash in December, and spawns in February and March, and that it is there the object of a regular but not very extensive fishery.

$\mathrm{Mr}$. Holdsworth further points out in his letter to me that he states in his book that the herring fishery takes place at Ramsgate in October and November, not the spawning, as in the citation given in my paper. With regard to the spawning, the statement in his book is that the herring are full at the eastern end of the Channel in November, and his impression is that the end of that month would be the general spawning-time in that locality. I am glad to correct this slight inaccuracy in my quotation of Mr. Holdsworth's observations. I assumed that some ripe, spawning herring were 
taken at Ramsgate in the first part of the fishing season, in October; and although Mr. Holdsworth doubts the validity of this assumption, it agrees with Yarrell's statement, already quoted, that the common or autumn herring deposits its spawn towards the end of October, supposing that this statement is intended to refer to the mouth of the Thames, which is probable, but not quite certain from the context. 